\title{
A Brief History of the USDA Motion Picture Service to 1943
}

\author{
By J. Emmett Winn
}

Spring 2013 Issue of KINEMA

A BRIEF HISTORY OF THE USDA MOTION PICTURE SERVICE TO 1943

The US Department of Agriculture (USDA) began producing films in the early 1900s and continued for decades. Millions saw these films in a wide variety of venues, including public schools, colleges and universities, civic meeting halls, libraries, church halls, and even open fields. Over the period of several decades, from the silent-movie era through the 1950s, the USDA was a significant government filmmaking organization, touting itself to be not only the first government agency to organize a filmmaking division but also the most prolific. The USDA motion picture branch was internationally respected, and the distribution of its films was high for US government institutions, particularly in the 1920s and 1930s. The USDA showed its films practically anywhere extension workers or others could gather a small group or a large crowd. The role of the films varied, but USDA administrators and filmmakers believed that all of the films spread the message of the USDA's agricultural work.

The history of the USDA's Motion Picture Service (MPS) ${ }^{(1)}$ demonstrates that it took its work very seriously and strove to produce quality films within its limited budget and resources. The MPS grew from a small group of enthusiasts within the USDA to a major division that produced hundreds of films over a period of several decades. In its earliest years the MPS operated on a level that was comparable to most film production, even in the commercial realm, but soon settled into a respected position in the governmental film arena.

There is no doubt that the USDA began producing films very early relative to other government agencies. In fact, the early MPS pioneers claimed that the USDA was the first government agency to produce a motion picture. For example, an MPS unit chief reported that in 1908, "when the Wright brothers came to Fort Myer [Fort Myers, Florida] to demonstrate their pioneer biplane for the Signal Corps, the Department of Agriculture made a film record of the demonstration - the first government motion picture."(2) Others have questioned this assertion; for instance, in their 1923 book, Motion Pictures in Education, Don Carlos Ellis and Laura Thornborough claim that the US Reclamation Service was the first "among the bureaus in Washington to take up this work, and . . . exhibited at the Jamestown Exposition 1907 films showing the work of the Government in reclaiming arid lands." ${ }^{(3)}$ However, the right to the claim of being the first government bureau to make a motion picture is of less importance than the fact that the USDA very quickly became a leader in government-sponsored motion pictures and was considered a model of success in the endeavour. ${ }^{(4)}$

The earliest motion picture work of the USDA was not part of its official duties and was performed without official departmental sanction. Ellis and Thornborough contend that the first USDA staff member to make a government film was Joseph Abel, a Bureau of Animal Industry photographer, who in 1909 "made a film of the live-stock show at the Alaska-Yukon Pacific Exposition and, later, films on the Texas Fever Tick and Its Eradication." ${ }^{(5)}$ These early efforts were concealed from USDA officials. According to the MPS staff, a film laboratory was established without the knowledge of the secretary of agriculture. The reason cited was that the USDA secretary at the time, "Tama Jim" Wilson, thought the "motion picture was the work of the devil." (6) This situation allegedly changed when O. H. Benson, a pioneer in the 4-H Club movement, surreptitiously set up a motion picture camera and filmed Secretary Wilson speaking to a group of "corn club boys." When the secretary saw the footage, "he was amazed and delighted - and from that moment the motion picture program of the Department ceased to be a bootleg enterprise."(7) Some reports cite C. Francis Jenkins as the camera person for this footage. ${ }^{(8)}$ Jenkins was a government clerk who later became an important film pioneer. ${ }^{(9)}$ Regardless of the exact reason for the legitimizing of filmmaking, the USDA film work continued in an ad hoc manner for several more years.

A modest film laboratory was established in 1912 in the USDA Section of Illustrations, where staff employees W. S. Clime and G. R. Goergens "were regularly assigned motion picture work."(10) The USDA and others have identified this as "the first Government motion picture laboratory to be established in the world."(11) 
Although the USDA staff members took such bragging rights very seriously, there is little historical evidence to confirm or deny these claims beyond the statements of the staff members in their written reports. However, the fact that the early USDA motion picture production was impressive and well respected in the educational film arena is not disputed. For example, Ellis and Thornborough argue that the USDA films had "considerable educational value" and "constituted the largest single collection of educational films on a related group of subjects." ${ }^{(12)}$ This, success in the early years, spanning from about 1908 to 1912, brought the USDA positive attention in the burgeoning film industry, both commercial and noncommercial.

The USDA's efforts were so successful that in September 1913 the agency formed "a temporary committee to determine whether the Department should enter the educational motion picture field in earnest."(13) Later that year the USDA established a permanent committee and authorized the Division of Publications (Section of Illustrations) to "purchase and install a complete motion picture photographic apparatus." (14) It was charged "to install a Motion Picture Laboratory, to purchase the necessary apparatus, and to produce motion pictures for visual instruction in agriculture under the direction of the motion picture committee."(15) Thus, in late 1913, the earliest official USDA motion picture unit was established. By most measures, the USDA's task was daunting, given that the USDA at that time consisted of seventeen different bureaus with wide-ranging responsibilities. Ellis and Thornborough cite this diversity as a main reason for the USDA's success in the government film arena, because all of its motion picture work was coordinated by a single film unit, thus the MPS was able to produce movies on a wide variety of topics. ${ }^{(16)}$ This variety tested the USDA filmmakers while also providing them with ample opportunities to experiment with new techniques and ideas.

Establishing what amounted to a small but fully functioning movie production studio within the federal government in early 1914 proved to be a challenge for the USDA staff. Early reports to the USDA secretary indicate that the MPS was experiencing problems and asking for patience. Since the MPS had a very small budget, the staff had to carefully research motion picture equipment before deciding what to purchase. For example, they performed a fairly extensive study of lighting to decide what would work best for their films. ${ }^{(17)}$ Moreover, faced with the problem of exhibiting their films in rural areas, the staff needed to understand the challenges of exhibition in a noncommercial environment. ${ }^{(18)}$

Eventually the MPS settled into a production strategy that began with the creation and approval of a basic scenario that mapped the subject matter and shots for the motion picture. ${ }^{(19)}$ Recording the images was simple at first; static camera setups filmed short vignettes, which were explained or augmented by the use of intertitles. The editing was simple and the films were generally short (usually one to four reels of film). As the MPS library of films grew over the years, it was necessary to revise some motion pictures "due to changes in agricultural methods and practices," and often films would need to be "withdrawn from circulation as they become obsolete." ${ }^{(20)}$

Distribution of the USDA movies was accomplished through two main methods. The primary distribution mode was lending the films, without charge beyond shipping, to the state USDA offices (very often to state extension agents) and other governmental, educational, and civic groups. The distribution was originally, and for many years, handled from the Washington, DC, office, which required that statistics on the audiences be returned with the motion pictures. The popularity of the movies soon surpassed the small number of film prints that the MPS budget allowed, and it became normal practice for the USDA to refuse hundreds of requests per year. The second method of distribution was direct purchase of film prints. For many years the USDA provided various ways for outside groups and foreign governments to purchase copies of their films at a nominal price relative to the cost of producing the prints. Sometimes the MPS made these copies in-house, but the most common method was to contract with a commercial firm to make prints directly for the buyers.

Film exhibition was accomplished in both commercial and noncommercial venues. Often the recipients of the movies, such as the state USDA agents, showed them in the field as part of a larger demonstration event. ${ }^{(21)}$ Several state USDA offices employed trucks outfitted with generators and exhibition equipment so that presentations could be made in any area, no matter how remote. ${ }^{(22)}$ Common public locations such as schools, libraries, churches, and social halls were also used to exhibit the films. In addition, USDA films often enjoyed commercial exhibition in movie theatres, where they were presented with "news weeklies" and other short, magazine-type non-feature programming that was common at the time. ${ }^{(23)}$ USDA films were 
also often shown as part of the war effort during World War I and World War II; for example, films promoting the backyard poultry movement were shown during World War I. ${ }^{(24)}$

Early on, the USDA learned that showing its motion pictures at USDA extension personnel presentations in rural communities drew larger audiences than talks without motion pictures. A November 1914 report explained that "the announcement that the motion picture exhibit was to be a feature of the lecture, attracted large audiences, even in bad weather and under difficult road conditions. . . . In every case, the motion picture exhibit brought out 75 to 100 people, where stereopticon talks attracted 10 to 20 ." (25) This result was consistently repeated, and it soon became obvious to the USDA that a major benefit of the films was in drawing larger crowds to its local meetings. The USDA saw this growing demand for its motion pictures at the same time that it was struggling to produce new films.

This led the USDA to consider allowing commercial film production companies to produce its motion pictures. Several film studios showed interest, including the Historical Film Company of New York and London, which offered to make films "of agricultural methods and all other ramifications to be used not only as records in the department in Washington, but for [the] department's missionary work throughout the country."(26) Although the USDA did not contract with the Historical Film Company, the department maintained a keen interest in commercial collaborations.

One successful USDA collaboration was with New York's Universal Film Manufacturing Company. After a USDA staff member resigned from the MPS to accept work with Universal, a USDA memorandum was issued that urged cooperation with the company, as it planned to make "sets of educational films illustrating the work of the Department." The memo indicated that this was "an opportunity for legitimate publicity" for the USDA. ${ }^{(27)}$ The USDA was interested in partnering with commercial film companies as a way to help stretch its small motion picture budget. Hence, USDA staff visited commercial film companies in New York in order to "determine whether we cannot enter into some valuable cooperative arrangement with the commercial houses." (28) The USDA ultimately decided that the only way it could control the content of its motion pictures was to produce them in-house, as "it soon became apparent that the Department could not . . . establish adequate censorship over its own subjects or make satisfactory financial arrangements covering the purchase of films" with the commercial houses; so the USDA abandoned the idea of allowing commercial interests to make all of the department's motion pictures. ${ }^{(29)}$

By 1917 the MPS staff reported that motion picture production was a staple of the USDA's work. ${ }^{(30)}$ Following US involvement in World War I, the MPS made films for the war effort "under the direction of the Committee on Public Information." (31) Many of the films addressed issues related to raising backyard poultry and home canning and preserving of foods. ${ }^{(32)}$ However, the largest USDA motion picture campaign in support of the war "dealt with farm labour, making appeals for the enlisting of city people in farm work." ${ }^{(33)}$ The USDA believed this promotion was very successful and reported that "a direct result" of the films was that many farm labourers were recruited. ${ }^{(34)}$

Even though the USDA had decided to produce the bulk of its films in order to maintain strict control over content, the department did not avoid all commercial collaborations. Interested in having its films distributed widely, the USDA approached several companies, including "Artcraft, Equitable, Metro, World, Brady, Fox, Triangle, Universal, Vitagraph, Edison, V.L.S.E., Ultra, Chester, Prizma, General, Paramount, Mutual, Pathe, International, Hoffman, Selznick, Educational, Argus, Gaumont, and Bluebird," (35) about distributing USDA films in commercial theatres. In 1918 the USDA entered into an agreement with the Universal Film Company. ${ }^{(36)}$ Universal screened several USDA films in commercial theatres, often as part of Universal's Screen Magazine series, with the first USDA film appearing in Universal Screen Magazine No. 47 with "subsequent releases . . . at least bi-monthly thereafter."(37) This agreement proved very successful; a 1918 USDA report estimates that four million people saw the USDA films exhibited in commercial theatres. ${ }^{(38)}$ The USDA was so pleased with these results that it had a filmic version of the USDA seal created for use in motion picture titles, thus improving their promotional value to the department. ${ }^{(39)}$ Despite its success, the USDA did not continue to contract exclusively with Universal for long but looked for ways to collaborate with other commercial entities. Consequently, its films continued to be shown in commercial theatres, in one manner or another, for several decades.

One particularly successful collaboration with a commercial film studio occurred in 1919, when the USDA 
purchased an animated film from Bray Studios titled The Charge of the Tick Brigade. ${ }^{(40)}$ The USDA avoided its concern about content control by approving the motion picture's scenario before allowing Bray Studios to produce the movie. The result was the USDA's first animated film, which proved to be a huge success with audiences. Years later, Raymond Evans, chief of the MPS, wrote that this "one-reel cartoon . . . was the spear-head of a long and arduous campaign that finally resulted in the eradication of the cattle fever tick from practically the whole continental United States." ${ }^{41)}$ The Charge of the Tick Brigade was an excellent example of a successful collaboration between the USDA and a commercial studio.

Interestingly, The Charge of the Tick Brigade and a related live-action film titled Mollie of Pine Grove Vat, also about tick eradication, may have been among the first motion pictures seen by some rural southern audiences. Years later a report from an MPS staff member claimed that "thousands of persons . . . in the hinterland districts of the South will remember this [Mollie of Pine Grove Vat] as the first motion picture they ever saw, as the . . motion picture truck carried [it] to many remote communities where commercial films had never been seen." ${ }^{(42)}$ The USDA considered these two motion pictures crucial to the success of the tick eradication effort because it believed that the films had been able to win over opponents of the USDA's campaign. ${ }^{(4)}$ For instance, one report described how a USDA movie truck driver and tick eradication agent, Ed F. Pickering, had shown Mollie of Pine Grove Vat to "an audience that included a crowd of bullies and the local 'bad man'" in a community hostile to tick eradication efforts, where "threats had been made to blow up the 'damn tick wagon." The film was so successful in promoting the USDA's work that after the movie, the "leader . . . shook hands with him [Pickering] before he left."

The MPS had achieved a good level of production for its resources by 1920. The previous year, they had completed twenty-six reels of film on eighteen different subjects and considered its production "greatly increased" over the earlier years' efforts. Moreover, the MPS reported that "the quality of films has been noticeably improved," (44) a particularly noteworthy comment since the MPS staff was sometimes criticized by others in the department for inconsistent quality in their films. ${ }^{(45)}$ Distribution concerns also were a problem for the MPS, as their budget did not allow them to make many prints of their motion pictures. However, 1920 also saw an improvement in this area when the department arranged for outside institutions and individuals to purchase copies of the motion pictures, thus relieving some of the budget concerns and resulting in what the MPS considered a "substantial increase in distribution of those films." (46) By this time the MPS was fairly well established in the production and distribution of its films, and the USDA saw value in this work.

As a result of its success, in 1922 the USDA constructed a new film lab for the MPS with better equipment; these improvements raised the USDA's facilities for filmmaking to a level "equal to those of any other producer of educational films." (47) The MPS believed that these improvements, along with its formal recognition as a distinct and separate unit reporting to the director of extension, demonstrated that motion pictures had become established as important to the USDA's "extension, educational, and publicity work." (48) As a result, the MPS completed twenty-eight new movies and revised forty-five older films in its library that year. ${ }^{(49)}$ This production brought the total MPS film collection to 169 subjects; 1,047 prints; and 1,237 reels of film. ${ }^{(50)}$

Moreover, between 1922 and 1923 the MPS reported an increase in audience attendance of approximately 2 million viewers, for a total of 4.46 million; it suggested, however that "allowance should be made for possible exaggeration, but this consideration is balanced by the fact that many users failed to report their showings. In addition, there are no figures available in regard to the exact size of the audiences reached by the department films that have been bought by cooperating or outside institutions."(51) Regardless of whether 4.46 million viewers is an accurate estimate, it is clear that by 1923 the USDA's motion pictures were reaching millions of viewers per year. It should be noted that audience members were not just noncommercial US audiences; the MPS 1923 annual report explains that portions of their films continued to be included on occasion in the commercial "news weeklies" distributed to commercial audiences and that some of their films were exhibited in Europe and at the Brazilian exposition in Rio de Janeiro. ${ }^{(52)}$

Film work at the MPS remained steady through the end of the 1920s. For example, the 1927 annual report explains that the MPS completed 18 new motion pictures, bringing the total of MPS films to 222 subjects in 1,792 positive copies for loan to a reported attendance of 4,300,864. USDA movie sales also continued, with 200 prints sold in 1927, including 80 purchased by ten foreign countries. ${ }^{(53)}$ The 1928 annual report 
gives a different indication of the distribution success of the USDA films, stating that the USDA made approximately 8,000 shipments of its motion pictures that year "for a total loan period of nearly 100,000 film days." According to the report, the USDA had to turn down 600 other requests "because of lack of copies to meet the demand." ${ }^{(54)}$

Prior to the end of the 1920s, the USDA films were available only in $35 \mathrm{~mm}$ format; however, by 1929 , individuals and institutions could purchase USDA films in $16 \mathrm{~mm},{ }^{(55)}$ and within a year the USDA began limited circulation in $16 \mathrm{~mm} .{ }^{(56)}$ Sales of USDA films (in both 16 and $35 \mathrm{~mm}$ ) continued at a consistent rate, with domestic sales being led by agricultural colleges, first and foremost, and by other higher education institutions. ${ }^{(57)}$ Foreign countries also continued to be very interested in purchasing USDA films; 1929's international buyers included Mexico, Australia, Japan, India, Turkey, New South Wales, Russia, and South Africa, among others. ${ }^{(58)}$ Additionally, the MPS produced a film titled Naturalized Plant Immigrants for the international exposition held in Seville, Spain, and provided copies of twenty-five of their existing films to also be shown. ${ }^{(59)}$ Hence, by 1929, thanks to this success, the demand for films far exceeded the MPS's ability to provide prints to its audiences by its traditional loan method. In addition, a technological revolution was occurring in the film industry, and so in 1929 the MPS began experimenting with sound pictures and soon realized that it would have to retool its production. ${ }^{(60)}$

An MPS staffer proclaimed the silent film "dead" in 1930. ${ }^{(61)}$ USDA filmmakers realized that "commercial developments made it possible to place sound projectors on the market at a price within the reach of users of Department films and there was a sudden demand for the 'talking' picture." ${ }^{62)}$ MPS filmmakers were concerned because they realized that the costs of sound production were well beyond their resources and facilities; however, they understood that several USDA units were very interested in the educational possibilities sound films might offer, particularly in the idea of a "canned lecture" that could be "illustrated with motion pictures . . . [as a] method of teaching." (63) Therefore the MPS began working toward the goal of producing sound films.

The issue of exhibiting sound pictures in the field was a concern for the USDA, and early on, the MPS suggested that state extension officers "provide projection trucks equipped for putting on good talking picture shows, and route them about the states in accordance with local demands." ${ }^{(64)}$ Moreover, in a further move away from 35-mm as the standard for USDA film exhibition, the MPS suggested the narrower width, because the $16 \mathrm{~mm}$ sound-on-disc equipment was easier to handle, and argued that "the same discs used with the 35 $\mathrm{mm}$. prints can be used with the $16 \mathrm{~mm}$. prints." (65) Overall, the MPS staff believed that local extension agents could better handle the $16 \mathrm{~mm}$ sound format in the field and preferred the sound-on-disc technologies to the sound-on-film technologies available at that time. ${ }^{(66)}$

In terms of production, the MPS realized that they had to immediately reimagine their filming practices, with one staffer saying, "The sudden advent of the 'talking' motion picture has necessitated a complete revision of the type of picture produced. No longer is it practicable to photograph persons in the act of talking so that lip movement is visible. All pictures which suggest an accompaniment of sounds are deleted, or so assembled that an accompaniment of sound may be furnished at a later date."(67) After reviewing both sound-on-disc and sound-on-film technologies, the MPS purchased disc sound projection equipment and began working on synchronized sound productions. ${ }^{(68)}$

By 1931 the MPS staff had established a mature film production studio and had transcended the act of simply manufacturing motion pictures; instead they were now dedicated to "develop[ing] a [film] laboratory along experimental lines, so that it might make a contribution to the motion picture art, especially as applied to educational work." (69) To that end, an MPS film engineer developed a device to allow for timelapse photography, which would be useful in filming such subjects as seed germination. ${ }^{(70)}$ The MPS also progressed well in its experimentations with sound projection and recording equipment and made some investigations into colour film production. ${ }^{(71)}$ Despite these advancements, the USDA saw a decrease in demand for its movies of approximately 15 percent due "largely to the fact that the demand for silent pictures [had] tended to abate since the advent of talking pictures." ${ }^{(72)}$ Nevertheless, the MPS continued the retooling to sound production and struggled to begin producing more sound pictures to meet the demand for "talking" movies.

The early 1930s saw the MPS grow to a staff of twenty-five permanent employees. ${ }^{(73)}$ The $16 \mathrm{~mm}$ format 
continued to grow in popularity because of its "ease of handling." (74) Complaints from borrowers about the condition of some of the movie prints prompted the MPS to institute a more rigorous system for inspecting the prints before they were shipped in order to remove from circulation prints that were badly marred. This system resulted in the USDA having fewer bookings but increased the satisfaction of borrowers. ${ }^{(75)}$ Sales of prints remained strong, with a total of 244 films sold in 1932 (45 of these purchased by foreign governments). ${ }^{(76)}$

The year 1932 saw the release of the first sound motion picture produced by the department, An International Study of American Roads. Although the sound is mostly a postproduction musical score played by the US Marine Band, the film included "an introductory speech . . . [by] Thomas H. MacDonald, Chief of Bureau of Public Roads of the Department." (77) The bulk of the motion picture was shot silently; however, the synchronized sound used on the speech was an important advance for the MPS in realizing their ambitions to produce "talking movies." Thus, by the end of 1932, the MPS could simultaneously record both images and sound in the studio and project sound movies in their facility using portable sound equipment. ${ }^{(78)}$ By 1934 the MPS had a total of 4,270 reels of film in its offerings, with 269 of them containing synchronized sound. ${ }^{(79)}$

The MPS staff's efforts were rewarded in 1935, when they were relocated into a new film production lab in the newly constructed Department of Agriculture South Building, which touted what one MPS staffer described as "the largest and best equipped [film lab] in the government service, including a commodious and well-appointed sound stage." ${ }^{(80)}$ The MPS settled into their new facilities and worked to regain the losses they had experienced with their delayed change to sound films. By 1938 the MPS was once again reporting annual audiences in excess of 5 million and routinely being forced to deny hundreds of requests per year due to a lack of prints. ${ }^{(81)}$ To help with this situation, the USDA established cooperative agreements with institutions, often state universities, to aid in handling the distribution of films to their users. ${ }^{\left({ }^{82}\right)}$ In addition, the MPS, cooperating with the Civilian Conservation Corps (CCC), provided the organization with fifteen hundred prints of USDA motion pictures to be used for educational activities. Through this agreement the MPS reported that more than ninety-nine thousand CCC "enrollees per month were given agricultural film study periods." (83) Thus, the USDA's film audiences had rebounded and grown with the addition of sound motion pictures to their offerings.

As the 1930s ended, the MPS reported that it had reached its limit with three thousand movie prints on approximately two hundred different subjects. In a statement the MPS staff explained that "this is about the maximum number of subjects that can be maintained, the annual discards now offsetting the annual accretions." ${ }^{(84)}$ Additionally, the MPS was unable to produce more than fifteen to twenty-five new films per year because of their limited resources. ${ }^{(85)}$

The early 1940s held many changes for the MPS. The sale of copies of their films was handled via annual contracts with commercial laboratories, and several hundred were ordered each year. ${ }^{\left({ }^{86}\right)}$ USDA films continued to be screened to millions of viewers, and the MPS began experimenting with Spanish-language versions of some of their films. For example, in 1942 the MPS began preparing a Spanish translation of The Battle Is in Our Hands, with Andrew Cordova as the Spanish narrator. Additionally that year, a Spanish-language version of Democracy at Work in Rural Puerto Rico was in production. ${ }^{(87)}$

However, the largest change occurred in 1943, when the MPS studio, the film lab, and fourteen staff members were transferred to the Office of the Coordinator of Information (later the Office of Strategic Services, OSS) to make films related to the war effort. The MPS reported that they were left "with a skeleton staff, inadequate production equipment and no suitable working space. However, we did have some cameras, editing equipment and trucks and with this as a nucleus we rented a building vacated by the Paramount Exchange in Washington and [continued] with our production." (88) Despite their reduced resources, the MPS continued to produce several films per year by contracting out sound, animation, and photographic lab work. ${ }^{\left({ }^{8}\right)}$ In December 1945 the borrowed staff and facilities were returned from the OSS to the USDA. The facilities included the "motion-picture laboratory, cutting rooms, storage vaults, projection rooms, sound stage and studio, animation studios, and other facilities." (90) The MPS reported that their unit was "the only civilian Government agency in Washington with complete facilities for motion picture production."(91) The MPS continued to make motion pictures for the USDA and other government agencies for several years. 
As radio and television played a more central role in the media, the MPS's role diminished until an in-house USDA film production unit was no longer viable. The NARA archives devoted to the records of the MPS end in 1958; it appears that the MPS was functionally inactive by that time. However, the history of the MPS is important to everyone interested in governmental and noncommercial film production. The USDA's efforts began during the early years of cinema and continued well into the era of television supremacy in the US media.

[Excerpt from Documenting Racism: African Americans in US Department of Agriculture Documentaries, 1921-42, by J. Emmett Winn, (02012. Reprinted by permission of the Continuum International Publishing Group.]

\section{Notes}

1. In this article I use the Motion Picture Service (MPS) to refer to the USDA unit that was charged with the production of motion pictures for the Department of Agriculture. This is consistent with the use of the term in USDA and is the term chosen to delineate the motion picture materials in the USDA archives. However, it is important to note that the unit was called a variety of different names during its existence, including the Office of Motion Pictures and the Division of Motion Pictures.

2. Evans, "U.S.D.A. Motion Picture Service, 1908-1943."

3. Ellis and Thornborough, Motion Pictures in Education, 17.

4. "U.S. Takes Lead in Educational Film Production," New York Herald Tribune, Sunday, April 1, 1928.

5. Ellis and Thornborough, Motion Pictures in Education, 18.

6. Evans, "U.S.D.A. Motion Picture Service, 1908-1943," 3.

7. Ibid.

8. Untitled report, n.d.

9. Ellis and Thornborough, Motion Pictures in Education, 10.

10. Untitled report, n.d.

11. Ibid., 17. Interestingly, Clime would later become a noted landscape painter.

12. Ellis and Thornborough, Motion Pictures in Education, 18.

13. Evans, "U.S.D.A. Motion Picture Service, 1908-1943," 4.

14. "No. 55, Regarding Motion Picture Activities of the Department," memorandum, December 18, 1913.

15. "From the Report of the Editor, Department of Agriculture, 1913-1916," n.d.

16. Ellis and Thornborough, Motion Pictures in Education, 19.

17. "For Mr. G. W. Wharton," memorandum, February 4, 1914.

18. "For Dr. Galloway," memorandum, February 16, 1914.

19. "No. 85, The Purchase of Motion-Picture Apparatus," memorandum, April 20, 1914.

20. C. W. Warburton, "A World Extension Course Conducted through U.S. Films," February 17, 1930, 2.

21. "To the Secretary of Agriculture on the Work of the Committee on Motion Picture Activities," memo- 
randum, November 30, 1914, 9.

22. "Motion Picture Policies of the U.S. Department of Agriculture," January 31, 1923.

23. "Annual Report of the Office of Motion Pictures," June 30, 1923; Ousley to Lemmle, December 5, 1917.

24. "Informal Report of Motion Picture Work, April 1 to 15, 1918," April 15, 1918.

25. "Report to the Secretary of Agriculture on the Work of the Committee on Motion Picture Activities," November 30, 1914, 8.

26. Ball to Huston, April 2, 1913.

27. "For Heads of Bureaus, Offices, and Independent Divisions," memorandum, May 24, 1913.

28. "For Dr. Galloway," memorandum, January 6, 1914.

29. "To the Secretary of Agriculture on the Work of the Committee on Motion Picture Activities," memo- 
randum, November 30, 1914, 2.

30. Evans, "U.S.D.A. Motion Picture Service, 1908-1943," 4.

31. Ibid., 5 .

32. Ibid.

33. "Use of Educational Motion Pictures," September 1929, 2.

34. Ibid.

35. "For the Secretary," memorandum, July 7, 1917.

36. Ousley to Bacon, July 25, 1917.

37. Ousley to Lemmle, December 5, 1917.

38. "From the Report of the Editor," 4.

39. "Informal Report on Motion Picture Work, March 1 to 15," March 8, 1918, 2.

40. "Informal Report of Motion Picture Work, April and May, 1919," n.d., 2.

41. Evans, "U.S.D.A. Motion Picture Service, 1908-1943," 5-6.

42. Ibid., 8 .

43. Chester A. Lindstrom, "Films Working for Agriculture," April 18, 1945, 2.

44. "Annual Report of the Office of Motion Pictures," June 30, 1919.

45. "Annual Report of the Office of Motion Pictures," June 30, 1923.

46. "Use of Educational Motion Pictures," September 1929, 2.

47. "A Statement of the History and Work of the Motion Picture Section, U.S.D.A.," 2.

48. "Annual Report of the Office of Motion Pictures," June 30, 1923.

49. Ibid.

Ibid.

Ibid.

Ibid.

53. "Annual Report of the Office of Motion Pictures," June 30, 1927.

54. "Annual Report of the Office of Motion Pictures," June 30, 1928.

55. "Annual Report of the Office of Motion Pictures," June 30, 1929, 2.

56. "Annual Report of the Office of Motion Pictures," July 3, 1931, 4.

57. "Farm Films Seen around the World," newspaper clipping, March 8, 1929.

58. Ibid.

59. "Annual Report of the Office of Motion Pictures," June 30, 1929.

60. "Statement of the History and Work of the Motion Picture Section, U.S.D.A.," 2.

61. "For Dr. Warburton, Director of Extension Work," memorandum, April 29, 1930.

62. "Statement of the History and Work of the Motion Picture Section, U.S.D.A.," 2.

63. "For Dr. Warburton," April 29, 1930.

64. Ibid., 2.

65. Ibid.

66. "Annual Report of the Office of Motion Pictures,"9 July 3, 1931, 5.

67. Ibid.

68. Ibid. 
May 29,1939.

85. Ibid.

86. "Statement of the History and Work of the Motion Picture Section, U.S.D.A.," 4.

87. "Report of Motion Picture Activities during the Month of June, 1942," July 14, 1942.

88. Chester A. Lindstrom, "Agricultural Motion Pictures and the War," September 29, 1943, 9-10.

89. Ibid.

90. "Condensed Annual Report, Motion Picture Service, Fiscal Year 1946-1947," November 18, 1947.

91. Ibid.

\section{References}

\section{Archival Sources}

Unless otherwise specified, all archival sources listed are from Record Group 16 of the National Archives and Records Administration, College Park, Maryland. Abbreviations used:

RDA - Records of the Dept. of Agriculture General Correspondence Relating to Negroes, 1909-1955.

HMPS - Records Relating to the History of the Motion Picture Service, 1908-1958.

ROSA - Records of the Office of the Secretary of Agriculture, General Correspondence of the Office of the Secretary, 1906-1970.

"Annual Report, Motion Picture Service, Calendar Year 1938," n.d., Box 1, Folder: Annual Reports 19371938. HMPS.

"Annual Report of the Office of Motion Pictures, Extension Service, U.S. Department of Agriculture, Fiscal Year Ending June 30, 1919," June 30, 1919, Box 1, Folder: Annual. HMPS.

"Annual Report of the Office of Motion Pictures, Extension Service, U.S. Department of Agriculture, Fiscal Year Ending June 30, 1923," June 30, 1923, Box 1, Folder: Annual. HMPS.

"Annual Report of the Office of Motion Pictures, Extension Service, U.S. Department of Agriculture, Fiscal Year Ending June 30, 1927," June 30, 1927, Box 1, Folder: Annual. HMPS.

"Annual Report of the Office of Motion Pictures, Extension Service, U.S. Department of Agriculture, Fiscal Year Ending June 30, 1928," June 30, 1928, Box 1, Folder: Annual. HMPS.

"Annual Report of the Office of Motion Pictures, Extension Service, U.S. Department of Agriculture, Fiscal Year Ending June 30, 1929," June 30, 1929, 2, Box 1, Folder: Annual. HMPS.

"Annual Report of the Office of Motion Pictures, Extension Service, U.S. Department of Agriculture, Fiscal Year Ending June 30, 1931," July 3, 1931, Box 1, Folder: Annual.

"Annual Report of the Office of Motion Pictures, Extension Service, U.S. Department of Agriculture, Fiscal Year Ending June 30, 1932," August 15, 1932, Box 1, Folder: USDA MPS Facilities.

Ball, Eustace Hale, to David Franklin Huston, April 2, 1913, Box 56, Folder: Moving Pictures 1912-1913. ROSA.

"Condensed Annual Report, Motion Picture Service, Fiscal Year 1946-1947," November 18, 1947, Box 1, Folder: Reports 7 Annual. HMPS.

Ellis, Don Carlos, and Laura Thornborough. Motion Pictures in Education: A Practical Handbook for Users of Visual Aids. New York: Cromwell, 1923.

Evans, Raymond. "The U.S.D.A. Motion Picture Service, 1908-1943," n.d. (probably 1943), Box 5, Folder: Educational Screen, Nov. 1937. 
"Farm Films Seen around the World," newspaper clipping from LaGrange, Georgia, March 8, 1929, Box 1437, Folder: Motion Pictures Jan.-June. ROSA.

"For Dr. Galloway," memorandum, January 6, 1914, Box 151, 1914. ROSA.

"For Dr. Galloway," memorandum, February 16, 1914, Box 151, Folder: 1914. ROSA.

"For Dr. Warburton, Director of Extension Work," memorandum, April 29, 1930, Box 2, Folder: Articles for Extension Review, 3-22-30 to 5-10-30. HMPS.

"For Heads of Bureaus, Offices, and Independent Divisions," memorandum, May 24, 1913, Box 56, Folder: Moving Pictures 1912-1913. ROSA

"For Mr. G. W. Wharton," memorandum, February 4, 1914, Box 151, Folder: 1914. ROSA.

"For the Secretary," memorandum, July 7, 1917, Box 415, Folder: Moving Pictures 1917. ROSA.

"From the Report of the Editor, Department of Agriculture, 1913-1916," n.d., Box 2, Folder: Motion Picture Service. HMPS.

"Informal Report on Motion Picture Work, March 1 to 15," March 8, 1918, Box 578, Folder: Moving Pictures 1918. ROSA.

"Informal Report on Motion Picture Work, April 1 to 15, 1918," April 15, 1918, Box 578, Folder: Moving Pictures 1918. ROSA.

Motion Picture Policies of the U.S. Department of Agriculture," January 31, 1923, Box 998, Folder: Moving Pictures Jan. 1-July 31. ROSA.

"Informal Report of Motion Picture Work, April and May, 1919," n.d., Box 683, Folder: Moving Pictures 1919. ROSA.

Lindstrom, Chester A. "Agricultural Motion Pictures and the War," September 29, 1943, Box 3, Folder: Paper prepared by Chester A. Lindstrom; delivered at the 54th semiannual Engineering Conference. HMPS.

\section{HMPS.}

. "Films Working for Agriculture," April 18, 1945, 2, Box 3, Folder: Films Working for Agriculture.

"No. 55, Regarding Motion Picture Activities of the Department," memorandum, December 18, 1913, Box 299, Folder: Moving Pictures. ROSA.

"No. 85, The Purchase of Motion-Picture Apparatus," memorandum, April 20, 1914, Box 299, Folder: Moving Pictures. ROSA.

Ousley, Clarence, to William Bacon, July 25, 1917, Box 415, Folder: Moving Pictures 1917. ROSA.

Ousley, Clarence, to Carl Lemmle, December 5, 1917, Box 415, Folder: Moving Pictures 1917. ROSA.

"Report of Motion Picture Activities during the Month of June, 1942," July 14, 1942, Box 5, Folder: Report on Defense Activities Monthly. HMPS.

"Report to the Secretary of Agriculture on the Work of the Committee on Motion Picture Activities," November 30, 1914, Box 2, Folder: Report on Work of the Committee on Motion Picture Activities. HMPS.

"Supplementary Statement concerning United States Department of Agriculture Motion Picture Work," May 29, 1939, Box 3048M, Folder: Motion Pictures. ROSA.

"A Statement of the History and Work of the Motion Picture Section, U.S.D.A.," n.d. (probably 1941), Box 2, Folder: History of Department Activities as They Related to Defense. HMPS.

"To the Secretary of Agriculture on the Work of the Committee on Motion Picture Activities," memorandum, November 30, 1914, Box 151, Folder: 1914. ROSA.

Tugwell, R. G., to John G. Bradley, December 28, 1934, Box 2032, Folder: Motion Pictures. ROSA.

Untitled report, n.d., Box 2, Folder: History of Motion Pictures. HMPS. 
"The Use of Educational Motion Pictures by the United States Department of Agriculture," September 1929, Box 2, Folder: Annual Reports of MP.

Warburton, C. W., to A. F. Woods, March 7, 1931, Box 1622, Folder: Motion Pictures (1 of 2). ROSA.

Warburton, C. W., "A World Extension Course Conducted through U.S. Films," February 17, 1930, Box 2, Folder: A World Extension Course. HMPS.

\section{Author Information}

J. Emmett WINN is Professor in the School of Communication and Journalism at Auburn University (Alabama). He is the author of Documenting Racism: African Americans in US Department of Agriculture Documentaries, 1921-42, The American Dream and Contemporary Hollywood Cinema, and co-editor of Transmitting the Past: Historical and Cultural Perspectives on Broadcasting. His scholarly articles have appeared in Critical Studies of Media Communication, The Journal of Broadcasting and Electronic Media, Film and History, among others. 